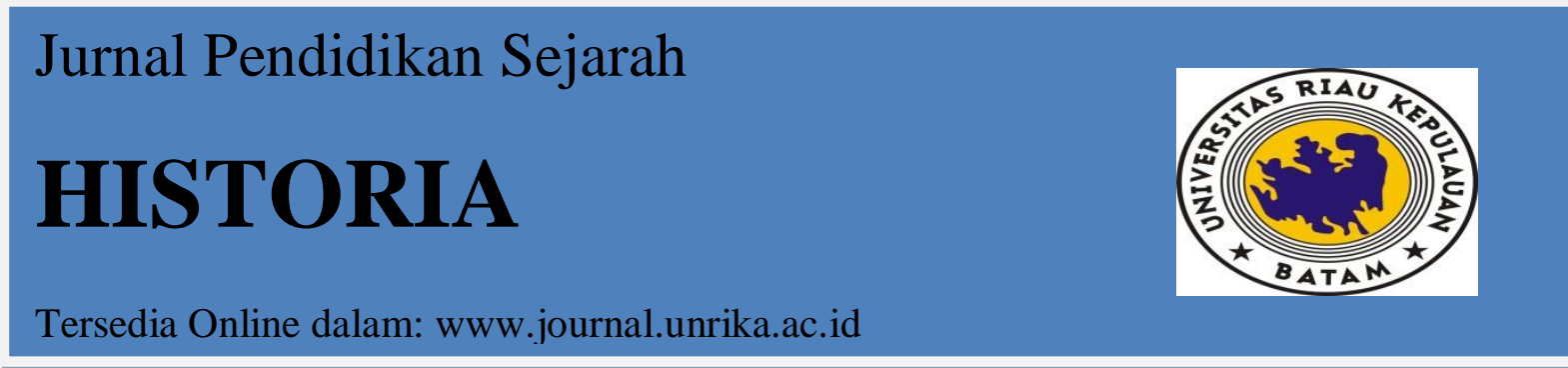

\title{
PENINGKATAN PARTISIPASI BELAJAR IPS MELALUI STRATEGI PEMBELAJARAN EVERYONE IS A TEACHER HERE SISWA KELAS VIII C SMP N 34 BATAM TAHUN PELAJARAN 2014/2015

\author{
INCREASING PARTICIPATION IPS LEARNING \\ THROUGH LEARNING STRATEGY EVERYONE IS A TEACHER HERE \\ STUDENT CLASS VIII C SMP N 34 BATAM LESSONS YEAR 2014/2015
}

\author{
KHADIJAH, S.E., M.M \\ Magister Manajemen, Universitas Terbuka, Indonesia \\ khadijah8421@yahoo.co.id
}

\begin{abstract}
Abstrak
Tujuan penelitian tindakan kelas ini adalah untuk mengetahui apakah strategi pembelajaran Everyone Is A Teacher Here dapat meningkatkan partisipasi belajar IPS siswa Kelas VIII C SMP N 34 Batam tahun pelajaran 2014/2015.

Penelitian ini menggunakan pendekatan kualitatif untuk mendapatkan data dan analisisnya melalui kajiankajian reflektif, partisipatif dan kolaboratif. Pengembangan program didasarkan data-data dan informasi dari siswa, guru dan setting sosial kelas secara alamiah melalui tiga tahapan siklus penelitian tindakan kelas. Maka prosedur pelaksanaan penelitian tindakan kelas ini meliputi: (1) perencanaan, (2) pelaksanaan tindakan, (3) observasi, dan (4) refleksi dalam setiap siklus.

Hasil penelitian menunjukkan bahwa strategi pembelajaran Everyone Is A Teacher Here terbukti dapat meningkatkan partisipasi belajar IPS siswa kelas VIII C SMP N 34 Batam. Partisipasi siswa pada refleksi awal sebesar 47,5\% siklus 1, pada siklus 2 sebesar $65 \%$ dan siklus 3 sebesar 77,5\%. Prosentase ini menunjukkan bahwa selama proses pembelajaran terjadi peningkatan 10\% setiap siklus partisipasi belajar IPS pada siswa kelas VIII C SMP N 34 Batam. Berdasarkan analisis hasil penelitian tersebut, maka peneliti merefleksi bahwa strategi pembelajaran Everyone Is A Teacher Here ini dapat meningkatkan partisipasi belajar siswa.
\end{abstract}

Kata Kunci: Strategi Pembelajaran Everyone Is A Teacher Here.

\begin{abstract}
The purpose of this action research was to determine whether the learning strategies Everyone Here Is A Teacher can increase the participation of social studies students Class VIII C SMP N 34 Batam school year 2014/2015.

This study used a qualitative approach to obtain data and analysis through studies reflective, participatory and collaborative. The development program was based data and information from students, teachers and social setting of the classroom naturally through the three stages of the cycle of action research. Then the procedures for implementing this action research include: (1) planning, (2) action, (3) observation, and (4) reflection in each cycle.
\end{abstract}


The results showed that the learning strategy Everyone Is A Teacher Here are proven to increase the participation of social studies class VIII C SMP N 34 Batam. Participation of students in the early reflections of 47,5\% first cycle, the second cycle of $65 \%$ and $77,5 \%$ for 3 cycles. Percentage shows that during the learning process there was an increase of $10 \%$ per cycle of participation in the social studies class VIII C SMP N 34 Batam. Based on the analysis of the results of the study, the researchers reflect that learning strategies Everyone Here Is A Teacher can increase the participation of student learning.

Keywords: Learning Strategies Everyone Here Is A Teacher.

\section{PENDAHULUAN}

Secara praktis, guru adalah ujung tombak dalam pembelajaran. Strategi dan manajemen guru untuk mengatasi masalah pembelajaran sangat dibutuhkan dalam upaya meningkatkan kualitas pembelajaran. Pelaksanaan pembelajaran di dalam kelas merupakan salah satu tugas utama guru, dan pembelajaran dapat diartikan sebagai kegiatan yang ditujukan untuk membelajarkan siswa. Dalam proses pembelajaran masih sering ditemui adanya kecenderungan meminimalkan keterlibatan siswa. Dominasi guru dalam proses pembelajaran menyebabkan kecenderungan siswa lebih bersifat pasif sehingga mereka lebih banyak menunggu sajian guru dari pada mencari dan menemukan sendiri pengetahuan, ketrampilan atau sikap yang mereka butuhkan.

Dalam implementasi materi, Muchtar (2006) menemukan IPS lebih menekankan aspek pengetahuan, berpusat pada guru, mengarahkan bahan berupa informasi yang tidak mengembangkan berpikir nilai serta hanya membentuk budaya menghafal dan bukan berpikir kritis. Dalam pelaksanaan Soemantri (2001) menilai pembelajaran IPS sangat menjemukan karena penyajiannya bersifat monoton dan ekspositoris sehingga siswa kurang antusias dan mengakibatkan pelajaran kurang menarik padahal menurut Sumaatmadja, Nursid (1996: 35) guru IPS wajib berusaha secara optimum merebut minat siswa karena minat merupakan modal utama untuk keberhasilan pembelajaran IPS.

Disisi lain Abimanyu (dalam Sukidin, 2002: 153). ada tiga faktor penyebab rendahnya partisipasi siswa dalam proses belajar mengajar, yaitu: (1) siswa kurang memiliki kemampuan untuk merumuskan gagasan sendiri; (2) siswa kurang memiliki keberanian untuk menyampaikan pendapat kepada orang lain; (3) siswa belum terbiasa bersaing menyampaikan pendapat dengan teman yang lain.

Sejalan dangan hal tersebut di atas, kondisi pembelajaran IPS terjadi pula di SMP N 34 Batam, guru masih menggunakan model pembelajaran yang kurang merangsang siswa untuk belajar lebih giat, dan proses pembelajaran masih menekankan pada aspek pengetahuan saja belum 
menyentuh kepada sikap dan keterampilan. Disamping itu, guru kurang mengacu pada pelibatan siswa secara aktif dalam proses pembelajaran. Kenyataan tersebut, menunjukkan bahwa proses yang dilakukan oleh guru untuk pembelajaran IPS belum aktif. Dengan demikian dapat diduga bahwa yang menjadi kendala yang dirasakan adalah masalah proses pembelajaran yang kurang variasi dan kurang melibatkan siswa secara aktif. Guru menggunakan model pembelajaran yang terkesan monoton sehingga siswa menjadi kurang aktif.

Berdasarkan hasil pengamatan awal diperoleh data sebagai berikut: (a) Partisipasi siswa dalam perolehan konsep sangat kurang, karena guru terlalu dominan dalam memberi informasi; (b) Suasana kelas kurang menyenangkan; (c) Kurang motivasi, karena jarang diberi penghargaan; (d) Buku yang dimiliki siswa hanya digunakan untuk mengerjakan latihan soal, sehingga fungsinya hanya untuk mengerjakan tugas yang diberikan guru.

Setelah memperhatikan situasi kelas yang seperti itu, maka perlu dipikirkan cara penyajian dan suasana pembelajaran IPS yang cocok untuk siswa, sehingga siswa dapat berpartisipasi aktif dalam proses pembelajaran. Saat ini pemerintah sudah sering mensosialisasikan berbagai model pembelajaran. Salah satu model pembelajaran yang disosialisasikan adalah model pembelajaran Everyone Is A Teacher Here.

Berdasarkan uraian di atas, tujuan penelitian tindakan kelas ini adalah untuk mengetahui apakah strategi pembelajaran Everyone Is A Teacher Here dapat meningkatkan partisipasi belajar IPS siswa Kelas VIII C SMP N 34 Batam tahun pelajaran 2014/2015. Penelitian tindakan kelas ini diharapkan bermanfaat bagi guru, akan dapat membantu mengatasi permasalahan pembelajaran yang dihadapi dan mendapat tambahan wawasan serta keterampilan pembelajaran yang digunakan untuk meningkatkan mutu pembelajaran. Sedangkan untuk siswa, akan memperoleh pelajaran IPS yang lebih menarik, meyenangkan dan memungkinkan bagi dirinya untuk memperoleh nilai-nilai yang sangat berguna bagi kehidupannya.

\section{METODE PENELITIAN}

Pengaturan Penelitian 
Penelitian tindakan kelas ini dilaksanakan di SMP N 34 Batam, untuk mata pelajaran IPS. Sebagai subyek dalam penelitian ini adalah siswa Kelas VIII C tahun pelajaran 2014/2015 semester genap dengan jumlah siswa sebanyak 40 orang, terdiri dari laki-laki 20 orang dan perempuan 20 orang. Pemilihan kelas ini bertujuan untuk memperbaiki dan meningkatkan proses pembelajaran di kelas VIII C SMP N 34 Batam. Penelitian tindakan kelas ini dilaksanakan selama 3 bulan dari bulan Februari sampai April 2015. Pertemuan waktu penelitian mengacu pada kalender akademik sekolah, karena penelitian tindakan kelas memerlukan beberapa siklus yang membutuhkan proses belajar mengajar yang efektif di kelas.

\section{Siklus Penelitian}

Penelitian tindakan kelas ini dilaksanakan melalui tiga siklus untuk melihat partisipasi belajar IPS siswa kelas VIII C SMP N 34 Batam melalui strategi pembelajaran Everyone Is A Teacher Here. Prosedur pelaksanaan penelitian tindakan kelas ini meliputi: (1) perencanaan, (2) pelaksanaan tindakan, (3) observasi, dan (4) refleksi dalam setiap siklus. Pada tahap perencanaan, guru peneliti bersama guru mitra membuat perencanaan pembelajaran yang mengembangkan partisipasi siswa dengan strategi Everyone Is A Teacher Here. Di sini, semua kegiatan yang akan dilaksanakan dimatangkan serta ditentukan alat yang digunakan untuk observasi tindakan yang dilakukan pada tahap tindakan, guru peneliti menyajikan pelajaran sesuai dengan rencana yang telah dirumuskan. Bersamaan dengan pelaksanaan tindakan, guru peneliti yang melakukan observasi dengan cara yang telah disepakati pada tahap perencanaan. Hasil observasi ini kemudian direfleksikan secara bersama untuk melihat kelebihan dan kekurangan yang digunakan untuk pelaksanaan tindakan selanjutnya.

\section{Instrumen Penelitian}

Untuk mendapatkan data yang valid dan dapat dipertanggungjawabkan, dalam penelitian ini digunakan beberapa instrumen pembantu, seperti lembar observasi, lembar catatan lapangan, dan studi dokumenter.

\section{PEMBAHASAN}

\section{Siklus I}


a. Perencanaan

* Guru peneliti menetapkan satu kali pertemuan atau 70 menit. Materi yang diberikan antara lain ketenagakerjaan.

* Guru peneliti bersama mitra membuat perangkat pembelajaran berupa Rencana Pelaksanaan Pembelajaran (RPP) dengan strategi pembelajaran Everyone Is A Teacher Here, dan membuat lembar kerja siswa.

* Guru membuat instrumen penelitian berupa lembar pengamatan kegiatan siswa, lembar pengamatan kegiatan guru, dan catatan lapangan.

b. Pelaksanaan Penelitian

Kegiatan Awal:

* Guru memberi salam.

* Guru memulai menyampaikan materi yang akan dipelajari.

* Guru menyampaikan garis besar tujuan pembelajaran hari itu, yaitu akan membahas materi ketenagakerjaan.

Kegiatan Inti:

* Guru memberikan sehelai kertas kepada siswa untuk menulis sebuah pertanyaan mengenai materi yang sudah dijelaskan, waktunya dibatasi 5 menit. Setelah selesai menulisnya kemudian kertas tersebut diberikan lagi ke guru. Guru memberikan apresiasi kepada siswa.

* Setelah semua pertanyaan terkumpul, guru memberikan lagi kertas-kertas tersebut kepada siswa tadi dibagi secara acak.

* Setelah siswa mendapatkan pertanyaan, guru meminta beberapa siswa untuk tunjuk jari manakala pertanyaan yang ada di tangannya penting untuk dibahas.

* Kemudian guru meminta siswa membacakan soal tersebut sekalian membacakan jawabannya tapi sebelumnya siswa diminta untuk mengamati dan memikirkan jawaban yang tepat.

* Setelah siswa memberikan jawabannya, siswa yang lain menanggapi apabila jawaban siswa yang lain tidak sama, guru memberikan kesempatan kepada beberapa siswa untuk memberikan jawaban lain. Guru memberikan apresiasi.

* Begitu seterusnya sampai beberapa siswa membacakan soal dan memberikan jawaban dan siswa yang lain menanggapi (30 menit).

\section{Kegiatan Akhir:}


* Bersama dengan siswa, guru membahas hasil kerja siswa.

* Guru memberikan kesimpulan bersama siswa.

\section{1) Kegiatan Observasi}

Kegiatan observasi dilaksanakan bersamaan dengan kegiatan di atas yang dilakukan oleh guru mitra sebagai kolaborator. Hasil observasi partisipasi belajar siswa dalam pembelajaran IPS selama siklus 1 adalah: skor perolehan di atas KKM sebanyak: 19 siswa, skor ideal adalah: 75 (sesuai KKM), prosentase sebesar: 47,5\%. Sedangkan hasil observasi kegiatan guru dalam pembelajaran IPS, pada siklus 1 masih tergolong rendah dengan perolehan skor 32 atau $61,54 \%$ sedangkan skor idealnya adalah 52. Data hasil observasi oleh kolaborator menunjukkan adanya hambatan yang datang dari siswa, yaitu:

a) Sebagian besar siswa Kelas VIII C pada umumnya partisipasi belajar IPS masih rendah dan pasif. Pada pertemuan siklus 1 ini guru banyak terlibat di dalam pembelajaran. Rendahnya partisipasi belajar IPS disebabkan rendahnya aktivitas belajar dan motivasi siswa.

b) Siswa dalam membuat pertanyaan masih banyak yang menyimpang dari topik yang dibahas dan sementara jawaban siswa masih banyak yang kurang sesuai dengan apa yang diharapkan.

c) Dalam menanggapi permasalahan, yang bisa menjawab hanya dilakukan siswa tertentu saja, itupun tanggapannya masih kurang relevan.

d) Siswa masih kurang memahami tentang strategi Everyone Is A Teacher Here.

e) Kemandirian belajar untuk mencari pengetahuan dan belajar sendiri masih rendah, siswa masih berharap bantuan dari temannya.

f) Selain itu kemampuan guru dalam mengorganisasikan siswa masih perlu perbaikan.

\section{2) Refleksi}

Refleksi dilakukan untuk mengamati keberhasilan dan kegagalan pelaksanaan tindakan yang terjadi pada siklus 1 maka perlu perbaikan diantaranya:

a) Guru belum terbiasa menciptakan suasana pembelajaran IPS melalui strategi Everyone Is A Teacher Here. Hal ini diperoleh hasil obeservasi terhadap aktivitas guru dalam pembelajaran IPS siklus pertama hanya memperoleh $61,54 \%$. 
b) Demikian juga dengan siswa belum terbiasa dengan kondisi pembelajaran IPS melalui strategi Everyone Is A Teacher Here. Hal ini diperoleh hasil obeservasi terhadap perolehan skor dalam pembelajaran IPS siklus pertama hanya memperoleh $47,5 \%$

c) Untuk memperbaiki kelemahan dan mempertahankan keberhasilan maka guru memberikan motivasi kepada siswa agar lebih aktif lagi dalam pembelajaran.

d) Guru memberi pengakuan atau penghargaan (reward).

e) Kemampuan guru dalam mengorganisasikan siswa masih perlu perbaikan dan hendaknya guru memperhatikan tahap-tahap kegiatan dan alokasi waktu yang telah ditetapkan.

\section{Siklus II}

a. Perencanaan tindakan pada siklus 2 dilakukan dengan memperhatikan hasil refleksi pada siklus 1, antara lain:

* Guru peneliti adalah membuat perencanaan pembelajaran (skenario pembelajaran) sesuai dengan kompetensi dasar.

* Guru membuat panduan belajar siswa agar mudah di pahami siswa

* Menyiapkan waktu yang tepat agar tidak banyak waktu yang terbuang.

* Menyiapkan materi pembelajaran dengan tujuan meningkatkan partisipasi belajar IPS siswa Kelas VIII C SMP N 34 Batam.

b. Pelaksanaan Tindakan

\section{$\underline{\text { Kegiatan Awal }}$}

Memeriksa kehadiran siswa, kebersihan dan kerapihan kelas.

* Guru menyampaikan garis besar tujuan pembelajaran dan memotivasi siswa .

* Guru menentukan topik bahasan yaitu akan membahas masalah tenaga kerja Indonesia dan dampak pengangguran terhadap keamanan lingkungan.

* Dengan tanya jawab guru melakukan apersepsi: mengapa pengangguran membawa dampak terhadap keamanan lingkungan?

\section{$\underline{\text { Kegiatan Inti: }}$}


* Guru memberikan sehelai kertas kepada siswa untuk menulis sebuah pertanyaan mengenai materi yang sudah dijelaskan tadi, waktunya dibatasi 5 menit. Setelah selesai menulisnya kemudian kertas tersebut diberikan lagi ke guru. Guru memberikan apresiasi kepada siswa.

* Setelah semua pertanyaan terkumpul, guru memberikan lagi kertas-kertas tersebut kepada siswa tadi dibagi secara acak.

* Setelah siswa mendapatkan pertanyaan, guru meminta beberapa siswa untuk tunjuk jari manakala pertanyaan yang ada di tangannya penting untuk dibahas.

* Kemudian guru meminta siswa membacakan soal tersebut sekalian membacakan jawabannya tapi sebelumnya siswa diminta untuk mengamati dan memikirkan jawaban yang tepat.

* Setelah siswa memberikan jawabannya, siswa yang lain menanggapi apabila jawaban siswa yang lain tidak sama, guru memberikan kesempatan kepada beberapa siswa untuk memberikan jawaban lain. Guru memberikan apresiasi.

* Begitu seterusnya sampai beberapa siswa membacakan soal dan memberikan jawaban dan siswa yang lain menanggapi (30 menit).

Kegiatan Akhir:

* Bersama dengan siswa, guru membahas hasil kerja siswa dilanjutkan dengan menghitung skor perkembangan.

* Memberikan penghargaan kepada siswa yang mendapat skor paling tinggi, dan kepada siswa yang palin berpartisipasi.

* Membuat rangkuman tentang pembelajaran hari itu, yaitu masalah permasalahan tenaga kerja, dan dampak pengangguran terhadap keamanan lingkungan.

- Menginformasikan materi yang akan dibahas pada pertemuan berikutnya, yaitu peningkatan mutu tenaga kerja, dan peran pemerintah dalam menanggunlangi masalah ketenagakerjaan di Indonesia.

c. Observasi

Kegiatan Observasi dilaksanakan bersamaan dengan kegiatan di atas yang dilakukan oleh guru mitra sebagai kolaborator. Hasil observasi partisipasi belajar siswa dalam pembelajaran IPS selama siklus 2 adalah: skor perolehan di atas KKM sebanyak: 26 siswa, skor ideal adalah: 75 (sesuai KKM), prosentase sebesar: 65\%. Sedangkan hasil observasi kegiatan guru dalam pembelajaran IPS pada siklus 2 ini tergolong sedang. Hal ini berarti mengalami perbaikan dari 
siklus pertama. Dari skor ideal 52 nilai yang diperoleh adalah 39 atau 75\%. Dari hasil observasi tersebut diketahui adanya peningkatan partisipasi belajar IPS siswa Kelas VIII C SMP N 34 Batam hal tersebut tampak seperti yaitu:

- Siswa rata-rata aktif karena siswa dalam memberi jawaban dan sudah ada yang berani mengungkapkan pendapatnya.

- Pertanyaan siswa sudah terarah pada materi yang dibahas.

- Jawaban siswa sebagian sudah relevan dengan materi yang di pelajari.

- Siswa telah dapat menyajikan materi dengan baik yang dikaitkan dengan materi pembelajaran yang berupa peristiwa-peristiwa di masyarakat.

Walaupun demikian masih ditemui hambatan-hambatan pada siklus 2, yaitu:

- Masih adanya siswa yang kurang aktif.

- Masih adanya jawaban siswa yang kurang relevan

- Motivasi dan minat siswa masih perlu ditingkatkan lagi

- Guru belum maksimal membangkitkan motivasi dan minat belajar siswa dan masih kurang memberi reward sebagai penguatan.

\section{d. Refleksi}

Dengan memperhatikan hasil pengamatan baik terhadap siswa maupun terhadap guru, diperoleh hal-hal sebagai berikut:

* Tingkat kinerja guru semakin baik, meskipun masih ada beberapa kekurangan. Hal ini dapat dilihat dari data observasi terhadap kegiatan guru IPS dalam pembelajaran meningkat dari $61,54 \%$ menjadi $75 \%$ pada siklus kedua.

* Siswa sudah mulai mampu berpartisipasi dalam pembelajaran, mampu menjawab, mampu mempresentasikan hasil kerja dengan baik. Hal ini dapat dilihat dari data observasi terhadap perolehan skor partisipasi belajar IPS pada siklus pertama dari 47,5\% menjadi $65 \%$ pada siklus kedua.

- Tetap meningkatkan pembelajaran dengan menggunakan strategi Everyone Is A Teacher Here sehingga partisipasi belajar IPS meningkat, seiring dengan meningkatnya motivasi dan minat belajar siswa.

\section{Siklus 3}


a. Perencanaan tindakan pada siklus 3 dilakukan dengan memperhatikan hasil refleksi pada siklus 2, antara lain:

* Hambatan pada siklus 2 oleh peneliti dan observer, dianalisa dan direfleksi untuk dijadikan pedoman dalam menyusun tindakan pada siklus 3.

* Guru membuat perencanaan pembelajaran (skenario pembelajaran) sesuai dengan kompetensi dasar.

- Guru membuat panduan belajar siswa agar mudah di pahami siswa.

- Menyiapkan waktu yang tepat agar tidak banyak waktu yang terbuang.

* Menyiapkan pokok bahasan tujuan meningkatkan partisipasi belajar IPS siswa Kelas VIII C SMP N 34 Batam.

b. Pelaksanaan Tindakan

Kegiatan Awal:

* Guru menyampaikan garis besar tujuan pembelajaran dan memotivasi siswa dengan pertanyaan bagaimana peranan pemerintah dalam mengatasi pengangguran?

* Guru melakukan apersepsi bagaimana caranya untuk meningkatkan mutu tenaga kerja?

* Guru menentukan topik bahasan peningkatan mutu tenaga kerja, dan peranan pemerintah dalam mengatasi masalah tenaga kerja di Indonesia.

$\underline{\text { Kegiatan Inti: }}$

* Guru memberikan sehelai kertas kepada siswa untuk menulis sebuah pertanyaan mengena materi yang sudah dijelaskan tadi, waktunya dibatasi 5 menit. Setelah selesai menulisnya kemudian kertas tersebut diberikan lagi ke guru. Guru memberikan apresiasi kepada siswa.

* Setelah semua pertanyaan terkumpul, guru memberikan lagi kertas-kertas tersebut kepada siswa tadi dibagi secara acak.

* Setelah siswa mendapatkan pertanyaan, guru meminta beberapa siswa untuk tunjuk jari manakala pertanyaan yang ada di tangannya penting untuk dibahas.

* Kemudian guru meminta siswa membacakan soal tersebut sekalian membacakan jawabannya tapi sebelumnya siswa diminta untuk mengamati dan memikirkan jawaban yang tepat.

* Setelah siswa memberikan jawabannya, siswa yang lain menanggapi apabila jawaban siswa yang lain tidak sama, guru memberikan kesempatan kepada beberapa siswa untuk memberikan jawaban lain. Guru memberikan apresiasi. 
* Begitu seterusnya sampai beberapa siswa membacakan soal dan memberikan jawaban dan siswa yang lain menanggapi (30 menit).

\section{Kegiatan Akhir:}

* Bersama dengan siswa, guru membahas hasil kerja siswa dilanjutkan dengan menghitung skor perkembangan.

* Memberikan penghargaan kepada siswa yang mendapat skor paling tinggi, dan kepada siswa yang paling berpartisipasi.

* Membuat rangkuman tentang pembelajaran hari itu, yaitu masalah peningkatan mutu tenaga kerja, dan peranan pemerintah dalam mengatasi masalah tenaga kerja di Indonesia.

* Menginformasikan materi yang akan dibahas pada pertemuan berikutnya, yaitu masalah sistem perekonomian Indonesia.

\section{c. Observasi}

Hasil observasi partisipasi belajar siswa dalam pembelajaran IPS selama siklus 3 diperolehan skor yaitu: skor perolehan di atas KKM sebanyak: 32 siswa, skor ideal adalah: 75 (sesuai KKM), prosentase sebesar: 77,5\%. Sedangkan hasil observasi kegiatan guru dalam pembelajaran IPS pada siklus 3 menperoleh skor perolehan 46 dari skor ideal 52 atau 88.46\%. Hal ini berarti menunjukkan adanya peningkatan yang sangat signifikan dan perbaikan dari siklus sebelumnya.

d. Refleksi

Keberhasilan yang diperoleh selama siklus 3 ini adalah sebagai berikut:

Siswa mulai mampu berpartisipasi dalam kegiatan dan tepat waktu dalam pembelajaran IPS seperti siswa mampu mempresentasikan hasil kerja yang diberikan guru. Partisipasi belajar siswa dalam pembelajaran IPS sudah mengarah ke pembelajaran Everyone Is A Teacher Here secara lebih baik. Hal ini dapat dilihat dari hasil observasi terhadap partisipasi belajar IPS dapat meningkat dari 47,5\% pada siklus kedua menjadi $65 \%$ pada siklus ketiga menjadi 77,5\%.

Meningkatnya partisipasi belajar siswa dalam pembelajaran IPS didukung oleh meningkatnya kegiatan aktivitas guru dalam mempertahankan dan meningkatkan suasana pembelajaran dengan strategi Everyone Is A Teacher Here. Hal ini dapat dilihat dari hasil observasi partisipasi belajar siswa dalam pembelajaran IPS mengalami peningkatan dari $75 \%$ pada siklus kedua dan menjadi $88,46 \%$ pada siklus ketiga. 
Penilaian siswa terhadap strategi pembelajaran Everyone Is A Teacher Here ini sangat positif, mereka menilai sangat menarik dan tidak membosankan.

Dari analisis hasil penelitian di atas, maka peneliti merefleksi bahwa strategi pembelajaran Everyone Is A Teacher Here ini dapat meningkatkan partisipasi belajar siswa.

\section{KESIMPULAN DAN SARAN}

\section{Kesimpulan}

1. Setelah dilakukan pengamatan terhadap kegiatan aktivitas siswa memperlihatakan bahwa terjadi peningkatan diperoleh rata-rata kadar partisipasi aktif siswa dalam pembelajaran IPS pada siklus 1 hanya rata-rata 47,5\% menjadi $65 \%$ pada siklus 2 , dan $77,5 \%$ pada siklus 3 .

2. Meningkatnya partisipasi belajar siswa dalam pembelajaran IPS didukung oleh meningkatnya kegiatan aktivitas guru dalam mempertahankan dan meningkatkan suasana pembelajaran dengan strategi Everyone Is A Teacher Here. Hal ini dapat dilihat dari data observasi terhadap kegiatan guru IPS dalam pembelajaran meningkat dari $61,54 \%$ pada siklus 1 , menjadi $75 \%$ pada siklus 2 dan menjadi $88,46 \%$ pada siklus 3 .

3. Karena dalam penelitian ini, skor rata-rata pada setiap siklus telah mencapai di atas $10 \%$, maka peneliti berkesimpulan bahwa strategi pembelajaran Everyone Is A Teacher Here sangat cocok digunakan dalam pembelajaran IPS dan dapat meningkatkan partisipasi siswa.

\section{Saran}

1. Guru hendaknya menyesuaikan metode dan strategi pembelajaran dengan materi yang disampaikan, guru sebagai pendidik hendaklah juga memahami karakteristik dan kemampuan siswa, karena masing-masing siswa pada dasarnya mempunyai karakter dan kemampuan yang berbeda-beda.

2. Karena kegiatan ini sangat bermanfaat khususnya bagi guru dan siswa, maka diharapkan kegiatan ini dapat dilakukan secara berkesinambungan dalam pembelajaran IPS maupun mata pelajaran lain. 


\section{REFERENSI}

Muhtar, S. (2006). Pengembangan Berfikir dan Nilai dalam Pendidikan IPS. Bandung: Gelar Pustaka Mandiri.

Sukidin, dkk. (2002). Manajemen Penelitian Tindakan Kelas. Surabaya: Insan Cendekia.

Numan Somantri M. (2001). Menggagas Pembaharuan Pendidikan IPS. Bandung: PT. Remaja Rosdakarya.

Sumaatmadja, Nursid (1996). Studi Geografi Suatu Pendekatan dan Analisis Keruangan. Bandung: Alumni. 